\title{
FAKTOR-FAKTOR YANG BERPENGARUH TERHADAP KINERJA KARYAWAN PADA PT. PANPLY KABUPATEN LUWU
}

\author{
Suhardi M. Anwar ${ }^{1}$, Ahmad Suardi $\mathbf{H}^{2}$, Ecce $^{3}$ \\ 1) Dosen Sekolah Tinggi Ilmu Ekonomi Muhammadiyah Palopo \\ 2,3) Dosen Sekolah Tinggi Ilmu Ekonomi Muhammadiyah Palopo
}

\begin{abstract}
Abstrak:Penelitian ini bertujuan untuk faktor-faktor yang berpengaruh terhadap kinerja karyawan pada PT. Panply Kabupaten Luwu. Variabel independen dalam penelitian ini adalah kemampuan, kepribadian, persepsi dan sikap sedangkan variabel dependen yaitu kinerja karyawan. Pengumpulan data dilakukan dengan membagikan kuesioner kepada 67 orang responden yang merupakan karyawan bagian pengangkutan kayu pada PT. Panply Kabupaten Luwu.

Berdasarkan hasil analisis data, Secara simultan variabel kemampuan, kepribadian, persepsi dan sikap berpengaruh signifikan terhadap kinerja karyawan. Hal ini dibuktikan dengan dengan uji secara simultan di mana diperoleh nilai $F$ hitung sebesar 20,133 lebih besar dari nilai F tabel yaitu 2,520 dan singnifikansi sebesar 0,000 lebih kecil dari 0,05 dengan persestase pengaruh sebesar 56,5\%. Sedangkan secara parsial dapat disimpulkan bahwa hanya variabel kemampuan dan sikap berpengaruh positif dan signifikan terhadap kinerja karyawan, sedangkan variabel kepribadian dan perpsepsi berpengaruh positif tapi tidak signifikan terhadap kinerja karyawan.

Oleh karena peneliti memberikan saran agar kiranya PT. Panply Kabupaten Luwu lebih memperhatikan tentang kemampuan dan sikap karyawan karena berdasarkan hasil penelitian ini kedua faktor tersebut berpengaruh positif dan signifikan terhadap kinerja karyawan.
\end{abstract}

Kata Kunci: Kemampuan, Kepribadian, Persepsi, Sikap, Kinerja Karyawan

\section{PENDAHULUAN}

Karyawan pada dasarnya merupakan unsur sumber daya yang sangat penting bagi organisasi untuk mencapai tujuan. Setiap karyawan dalam suatu organisasi selalu mengharapkan adanya perubahan baik segi materil maupun spritual yang mempunyai kaitan sangat erat dengan kinerjanya sebagai unsur utama yang dapat menentukan keberhasilan suatu organisasi.

Demi tercapainya tujuan organisasi, karyawan memerlukan motivasi untuk bekerja lebih rajin. Melihat pentingnya karyawan dalam organisasi, maka karyawan diperlukan perhatian lebih serius terhadap tugas yang dikerjakan sehingga tujuan organisasi dapat tercapai dengan baik.

Sumber daya manusia berperan dalam mengolah dan memanfaatkan sumber daya dan material sehingga menjadi produk. Oleh karena itu untuk meningkatkan kinerja, perlu diperhatikan agar sumber daya manusia dapat bekerja secara efisien dan efektif serta menampilkan kinerja yang bisa memberi sumbangan terhadap produktivitas merupakan masalah mendasar dari berbagai konsep manajemen sumber daya manusia.

Kinerja individu adalah bagaimana seorang karyawan melaksanakan pekerjaannya atau untuk kerjanya. Kinerja karyawan yang meningkat akan turut mempengaruhi/meningkatkan prestasi organisasi tempat karyawan yang bersangkutan bekerja, sehingga tujuan organisasi yang telah ditentukan dapat dicapai. Dimana tujuan-tujuan organisasi telah dirancang untuk bisa dilaksanakan secara efektif dan efisien. Salah satu faktor yang mempengaruhi peningkatan prestasi kerja 
karyawan dalam suatu organisasi adalah karakteristik individu karyawan (person characteristic) yang terdiri dari kemampuan, kepribadian, persepsi dan sikap. Karakteristik individu merupakan perbedaan dari masingmasing karyawan yang dapat mempengaruhi dalam berperilaku dan melakukan suatu pekerjaan.

Secara signifikan kendala utama seseorang dalam melaksanakan pekerjaan berhubungan erat dengan karakteristik seseorang baik dari segi kemampuan dan keterapilan, masa kerja, pendidikan dan kebutuhan mereka. Karakteristik individu sangat menunjang seseorang dalam melaksanakan pekerjaan dan akan memberikan kontribusi positif terhadap keberhasilan dan kelangsungan organisasi. Berkaitan dengan fenomena inilah serta pentingnya sumber daya manusia dalam setiap organisasi, maka banyak organisasi menerapkan manajemen sumber daya manusia yang lebih strategis, yang tentunya dimaksudkan tidak hanya untuk mengembangkan kemampuan mereka saja namun yang lebih penting dari itu adalah untuk membangun dan meningkatkan hubungan emosional, sinergi dan rasa kebersamaan dengan organisasi.

Upaya menciptakan kinerja melalui peningkatan prestasi kerja karyawan PT. Panply Kabupaten Luwu, nampaknya masih terdapat banyak kendala yang dihadapi sehingga sulit untuk mencapai tujuan organisasi secara maksimal. Kondisi yang belum ideal masih ada karyawan di PT. Panply Kabupaten Luwu. Dimana masih ada kendala lain di PT. Panply Kabupaten Luwu antara lain karyawan bekerja tidak maksimal disebabkan karena pengalaman dan tanggung jawabnya rendah serta masa kerjanya yang masih baru, sehingga mengakibatkan kinerja karyawan menurun sehingga pekerjaan tidak dapat terselesaikan sesuai dengan yang direncanakan.

Dalam kaitannya dengan peningkatan prestasi kerja karyawan, hal tersebut tentunya harus segera dibenahi agar para pimpinan dan bawahan pada PT. Panply Kabupaten Luwu dapat melaksanakan tugas dan tanggungjawabnya dengan sehingga target yang ingin dicapai oleh perusahaan dapat tercapi secara maksimal.

\section{BAHAN DAN METODE}

Jenis dan sumber data dalam penelitian ini yaitu data primer dan sekunder. Populasi dalam penelitian ini adalah seluruh karyawan bagian pengangkutan kayu pada PT. Panply Kabupaten Luwu yang berjumlah 67 orang karyawan. (PT. Panply Kabupaten Luwu). pengambilan sampel dalam penelitian dengan mengambil semua jumlah populasi yaitu sebanyak 67 responden sebagai sampel dalam penelitian ini. Metode pengumpulan data penulis lakukan adalah penelitian lapangan terdiri dari observasi, wawancara, koesioner. Metode analisis data terdiri dari analisis deskriptif dan regresi berganda dengan rumus sebagai berikut:

$$
\begin{aligned}
& \mathrm{Y}=\mathrm{a}+\mathrm{b}_{1} \mathrm{X}_{1}+\mathrm{b}_{2} \mathrm{X}_{2}+\mathrm{b}_{3} \mathrm{X}_{3}+\mathrm{b}_{4} \mathrm{X}_{4} \\
& \text { + e Dimana: } \\
& \mathrm{Y} \quad=\text { Kinerja karyawan } \\
& \mathrm{X}_{1}=\text { Kemampuan } \\
& \mathrm{X}_{2}=\text { Kepribadian } \\
& \mathrm{X}_{3}=\text { Persepsi } \\
& \mathrm{X}_{4}=\text { Sikap } \\
& \text { a }=\text { Konstant } \\
& \mathrm{b}_{1}, \mathrm{~b}_{2}, \mathrm{~b}_{3}, \mathrm{~b}_{4}=\text { Koefisien regresi } \\
& \text { e } \quad=\text { Error }
\end{aligned}
$$




\section{HASIL DAN PEMBAHASAN}

\section{Karakteristik Responden}

Karateristik responden berdasarkan jenis kelamin

\begin{tabular}{lcc}
\hline \hline Jenis Kelamin & Jumlah & Persentase \\
\hline \hline Laki-laki & 67 & 100 \\
Perempuan & 0 & 0 \\
\hline \hline \multicolumn{1}{c}{ Total } & $\mathbf{6 7}$ & $\mathbf{1 0 0}$ \\
\hline \hline
\end{tabular}

Sumber : Data Primer, 2015

Dari Tabel di atas tentang karakteristik responden berdasarkan jenis kelamin, dapat diketahui bahwa jumlah responden yang berjenis kelamin laki-laki sebanyak 67 orang atau sekitar $100 \%$ dari keseluruhan jumlah responden. Hal ini membuktikan bahwa profesi sebagai karyawan bagian pengangkutan kayu pada PT. Panply Kabupaten Luwu lebih membutuhkan laki-laki, karena pekerjaan ini membutuhkan tenaga yang besar.

\section{Karateristik responden berdasarkan usia}

\begin{tabular}{ccc}
\hline \hline Usia & Jumlah & Persentase \\
\hline \hline $25-30$ tahun & 30 & 45 \\
$31-35$ tahun & 21 & 31 \\
$36-40$ tahun & 6 & 9 \\
$>40$ tahun & 10 & 15 \\
\hline \hline Total & $\mathbf{6 7}$ & $\mathbf{1 0 0}$ \\
\hline \hline
\end{tabular}

Sumber : Data Primer, 2015

Dari Tabel di atas tentang karakteristik responden berdasarkan usia, dapat diketahui bahwa jumlah responden yang berusia $25-30$ tahun sebanyak 30 orang atau sekitar $45 \%$ dari keseluruhan jumlah responden, responden yang berusia 31 -35 tahun sebanyak 21 orang atau sekitar $21 \%$ dari keseluruhan jumlah responden, responden yang berusia 36 - 40 tahun sebanyak 6 orang atau sekitar 9\% dari keseluruhan jumlah responden dan responden yang berusia $>40$ tahun tahun sebanyak 10 orang atau sekitar $15 \%$ dari keseluruhan jumlah responden. Hal ini menunjukkan bahwa usia responden pada penelitian ini masih tergolong usia yang produktif sehingga memungkinkan terjadinya peningkatan produksi PT. Panply Kabupaten Luwu.

Karateristik responden berdasarkan pendidikan

\begin{tabular}{|c|c|c|}
\hline $\begin{array}{c}\text { Pendidikan } \\
\text { Terakhir }\end{array}$ & Jumlah & Persentase \\
\hline 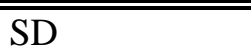 & 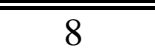 &  \\
\hline SMP & 15 & 22 \\
\hline SMA & 44 & 66 \\
\hline Total & 67 & 100 \\
\hline
\end{tabular}

Sumber : Data Primer, 2015

Dari Tabel di atas tentang karakteristik responden berdasarkan pendidikan terakhir, dapat diketahui bahwa jumlah responden yang berpendidikan terakhir SD sebanyak 8 orang atau sekitar $12 \%$ dari keseluruhan jumlah responden, responden yang berpendidikan terkahir SMP sebanyak 15 orang atau sekitar $22 \%$ dari keseluruhan jumlah responden dan responden yang berpendidikan terakhir SMA sebanyak 44 orang atau sekitar $66 \%$ dari keseluruhan jumlah responden. Hal ini menunjukkan bahwa sebagian besar responden hanya mampu menyelesaikan pendidikan sampai Sekolah Menengah Atas (SMA) dikarenakan pekerjaan sebagai karyawan pengangkutan kayu di PT. Panply Kabupaten Luwu tidak memerlukan pendidikan yang tinggi. 
Karateristik responden berdasarkan lama kerja

\begin{tabular}{|c|c|c|}
\hline Lama Bekerja & Jumlah & Persentase \\
\hline $1-5$ tahun & 29 & 43 \\
\hline $6-10$ tahun & 12 & 18 \\
\hline $10-15$ tahun & 20 & 30 \\
\hline$>15$ tahun & 6 & 9 \\
\hline Total & 67 & 100 \\
\hline
\end{tabular}

Sumber : Data Primer, 2015

Dari Tabel di atas tentang karakteristik responden berdasarkan lamanya bekerja, dapat diketahui bahwa jumlah responden yang yang bekerja selama $1-5$ tahun sebanyak 29 orang atau sekitar $43 \%$ dari keseluruhan jumlah responden, responden yang bekerja selama $6-10$ tahun sebanyak 12 orang atau sekitar $18 \%$ dari keseluruhan jumlah responden, responden yang bekerja selama 10 - 15 tahun sebanyak 20 orang atau sekitar 30\% dari keseluruhan jumlah responden dan responden yang bekerja > 15 tahun sebanyak 6 orang atau sekitar 9\% dari keseluruhan jumlah responden. Hal ini menunjukkan bahwa sebagian besar responden telah bekerja rata-rata selama 15 tahun, berarti karayawan bagian pengangkutan kayu pada PT. Panply Kabupaten Luwu mempunyai pengalaman kerja yang mampu menunjang peningkatan kinerja karayawan bagian pengangkutan kayu pada PT. Panply Kabupaten

\section{Uji Validitas dan Reliabilitas Instrumen Uji Validitas}

Uji validitas instrumen dalam penelitian ini menggunakan metode pengujian validitas isi dengan analisis item. Biasanya instrument dianggap valid apabila memenuhi syarat minimum $\mathrm{r}=0,30$. Kalau korelasi antara butir instrument dengan skor total kurang atau $r$ kurang dari 0,30, maka butir dalam instrument tersebut dinyatakan tidak valid. Adapun uji validitas untuk masingmasing variabel dalam penelitian ini yang dibagikan kepada 30 orang dapat kita lihat pada Tabel di bawah ini:

\begin{tabular}{|c|c|c|c|}
\hline Variabel & $\begin{array}{c}\mathrm{r} \\
\text { Hitung } \\
\end{array}$ & $\begin{array}{c}\mathbf{r} \\
\text { Minimum } \\
\end{array}$ & Keterangan \\
\hline $\begin{array}{l}\text { Kemampu } \\
\text { an (X1) } \\
\text { Item 1 } \\
\text { Item } 2 \\
\text { Item } 3\end{array}$ & $\begin{array}{l}0,439 \\
0,621 \\
0,478\end{array}$ & $\begin{array}{l}0,30 \\
0,30 \\
0,30\end{array}$ & $\begin{array}{l}\text { Valid } \\
\text { Valid } \\
\text { Valid }\end{array}$ \\
\hline $\begin{array}{l}\text { Kepribadi } \\
\text { an (X2) } \\
\text { Item 1 } \\
\text { Item } 2 \\
\text { Item 3 }\end{array}$ & $\begin{array}{l}0,384 \\
0,597 \\
0,620\end{array}$ & $\begin{array}{l}0,30 \\
0,30 \\
0,30\end{array}$ & $\begin{array}{l}\text { Valid } \\
\text { Valid } \\
\text { Valid }\end{array}$ \\
\hline $\begin{array}{l}\text { Persepsi } \\
\text { (X3) } \\
\text { Item 1 } \\
\text { Item } 2 \\
\text { Item } 3 \\
\end{array}$ & $\begin{array}{l}0,627 \\
0,517 \\
0,374\end{array}$ & $\begin{array}{l}0,30 \\
0,30 \\
0,30\end{array}$ & $\begin{array}{l}\text { Valid } \\
\text { Valid } \\
\text { Valid }\end{array}$ \\
\hline $\begin{array}{l}\text { Sikap } \\
(\mathrm{X} 4) \\
\text { Item } 1 \\
\text { Item } 2 \\
\text { Item 3 } \\
\end{array}$ & $\begin{array}{l}0,384 \\
0,597 \\
0,620\end{array}$ & $\begin{array}{l}0,30 \\
0,30 \\
0,30\end{array}$ & $\begin{array}{l}\text { Valid } \\
\text { Valid } \\
\text { Valid }\end{array}$ \\
\hline $\begin{array}{l}\text { Kinerja } \\
\text { Karyawan } \\
(Y) \\
\text { Item } 1 \\
\text { Item } 2 \\
\text { Item } 3 \\
\text { Item } 4\end{array}$ & $\begin{array}{l}0,734 \\
0,478 \\
0,311 \\
0,734\end{array}$ & $\begin{array}{l}0,30 \\
0,30 \\
0,30 \\
0,30\end{array}$ & $\begin{array}{l}\text { Valid } \\
\text { Valid } \\
\text { Valid } \\
\text { Valid }\end{array}$ \\
\hline
\end{tabular}
Luwu. 
Dari Tabel di atas tentang uji validitas di atas dapat kita lihat bahwa nilai $\mathrm{r}$ hitung untuk setiap item pernyataan tentang untuk semua variabel dalam penelitian ini memiliki korelasi yang lebih besar dari batasan minimum nilai $\mathrm{r}$ yaitu 0,30 maka semua pernyataan untuk semua variabel dalam penelitian dianggap valid.

\section{Uji Reliabilitas}

Uji reliabilitas menyatakan bahwa apabila instrumen yang digunakan beberapa kali untuk mengukur objek yang sama akan menghasilkan data yang sama. Menurut Perry Roy Hilton and Charlotte Brownlow dalam bukunya SPSS Explained (2004:364), mengatakan bahwa untuk pengambilan keputusan pada uji realibilitas biasanya menggunakan batasan 0,60. Dalam hal ini, realibilitas kurang dari 0,60 adalah kurang baik, sedangkan 0,70 adalah dapat diterima dan lebih dari 0,80 dianggap baik.

Adapun uji reliabilitas untuk semua variabel dalam penelitian ini dapat kita lihat pada Tabel berikut:

\begin{tabular}{|l|c|c|}
\hline \multicolumn{1}{|c|}{ Variabel } & $\begin{array}{c}\text { Alpha } \\
\text { Cronbach }\end{array}$ & Keterangan \\
\hline Kemampuan (X1) & 0,692 & Reliabel \\
\hline Kepribadian (X2) & 0,709 & Reliabel \\
\hline Persepsi (X3) & 0,687 & Reliabel \\
\hline Sikap (X4) & 0,709 & Reliabel \\
\hline Kinerja Karyawan (Y) & 0,756 & Reliabel \\
\hline
\end{tabular}

Dari Tabel di atas tentang uji reliabilitas di atas, diperoleh nilai Cronbach's Alpha untuk semua variabel dalam penelitian ini lebih besar dari 0,60 . Hal ini membuktikan bahwa pernyataan tentang semua variabel dalam penelitian ini adalah baik atau realibel.
Dari hasil analisis, maka dapat disimpulkan bahwa variabel kemampuan, kepribadian, persepsi dan sikap secara simultan berpengaruh signifikan terhadap kinerja karyawan. Hal ini dibuktikan dengan dengan uji secara simultan di mana diperoleh nilai F hitung sebesar 20,133 lebih besar dari nilai $\mathrm{F}$ tabel yaitu 2,520 dan singnifikansi sebesar 0,000 lebih kecil dari 0,05 dengan persestase pengaruh sebesar $56,5 \%$.

Sedangkan untuk pengujian secara parsial akan dijabarkan sebagai berikut:

\section{Pengaruh Kemampuan terhadap Kinerja Karyawan}

Hasil analisis secara parsial dapat disimpulkan bahwa kemampuan berpengaruh positif dan signifikan terhadap kinerja karyawan. Hal ini dibuktikan dengan uji secara parsial diperoleh koefisien regresi untuk variabel kemampuan bernilai positif $(0,437)$ yang berarti bahwa setiap peningkatan kemampuan akan mempengaruhi peningkatan kinerja karyawan.

Sedangkan untuk uji $\mathrm{t}$ diperoleh nilai $\mathrm{t}$ hitung sebesar 4,124 lebih besar dari nilai t tabel yaitu 1,999 dan signifikansi sebesar 0,000 lebih kecil dari 0,05 maka dapat disimpulkan bahwa variabel kemampuan berpengaruh signifkan terhadap kinerja karyawan.

\section{Pengaruh Kepribadian terhadap Kinerja Karyawan}

Hasil analisis secara parsial dapat disimpulkan bahwa kepribadian berpengaruh positif tapi tidak signifikan terhadap kinerja karyawan. Hal ini dibuktikan dengan uji secara parsial diperoleh koefisien regresi untuk variabel kepribadian bernilai positif $(0,280)$ yang berarti

\section{Pembahasan}


bahwa setiap peningkatan kepribadian akan mempengaruhi peningkatan kinerja karyawan.

Sedangkan untuk uji $\mathrm{t}$ diperoleh nilai $\mathrm{t}$ hitung sebesar 1,859 lebih kecil dari nilai t tabel yaitu 1,999 dan signifikansi sebesar 0,068 lebih besar dari 0,05 maka dapat disimpulkan bahwa variabel kepribadian tidak berpengaruh signifkan terhadap kinerja karyawan.

\section{Pengaruh Persepsi terhadap Kinerja Karyawan}

Hasil analisis secara parsial dapat disimpulkan bahwa persepsi berpengaruh positif tapi tidak signifikan terhadap kinerja karyawan. Hal ini dibuktikan dengan uji secara parsial diperoleh koefisien regresi untuk variabel persepsi bernilai positif $(0,054)$ yang berarti bahwa setiap peningkatan kepribadian akan mempengaruhi peningkatan kinerja karyawan.

Sedangkan untuk uji $\mathrm{t}$ diperoleh nilai $\mathrm{t}$ hitung sebesar 0,471 lebih kecil dari nilai t tabel yaitu 1,999 dan signifikansi sebesar 0,639 lebih besar dari 0,05 maka dapat disimpulkan bahwa variabel persepsi tidak berpengaruh signifkan terhadap kinerja karyawan.

\section{Pengaruh Sikap terhadap Kinerja Karyawan}

Hasil analisis secara parsial dapat disimpulkan bahwa sikap berpengaruh positif dan signifikan terhadap kinerja karyawan. Hal ini dibuktikan dengan uji secara parsial diperoleh koefisien regresi untuk variabel kemampuan bernilai positif $(0,611)$ yang berarti bahwa setiap peningkatan sikap akan mempengaruhi peningkatan kinerja karyawan.

Sedangkan untuk uji $\mathrm{t}$ diperoleh nilai $\mathrm{t}$ hitung sebesar 3,760 lebih besar dari nilai t tabel yaitu 1,999 dan signifikansi sebesar 0,000 lebih kecil dari 0,05 maka dapat disimpulkan bahwa variabel sikap berpengaruh signifkan terhadap kinerja karyawan.

Hasil penelitian ini sejaan dengan pendapatn Robbins (2008:56), bahwa variabel ditingkat individu meliputi karakteristik biografis, kemampuan, kepribadian, proses belajar, persepsi, sikap dan kepuasan kerja. Pengaruh karakteristik individu terhadap kinerja karyawan terjadi karena karyawan bekerja sesuai kemampuan, kepribadian, persepsi dan sikap serta taat pada aturan kerja atau beretika dalam bekerja. Sehingga karyawan sudah menyelesaikan pekerjaannya yang pada akhirnya berdampak positif pada kinerja karyawan.

\section{SIMPULAN}

1) Secara simultan variabel kemampuan, kepribadian, persepsi dan sikap berpengaruh signifikan terhadap kinerja karyawan. Hal ini dibuktikan dengan dengan uji secara simultan di mana diperoleh nilai $\mathrm{F}$ hitung sebesar 20,133 lebih besar dari nilai $F$ tabel yaitu 2,520 dan singnifikansi sebesar 0,000 lebih kecil dari 0,05 dengan persestase pengaruh sebesar $56,5 \%$.

2) Secara parsial dapat disimpulkan bahwa kemampuan berpengaruh positif dan signifikan terhadap kinerja karyawan. Hal ini dibuktikan dengan uji secara parsial diperoleh koefisien regresi untuk variabel kemampuan bernilai positif $(0,437)$ yang berarti bahwa setiap peningkatan kemampuan akan mempengaruhi peningkatan kinerja karyawan. Sedangkan untuk uji t diperoleh nilai t hitung sebesar 4,124 lebih besar dari nilai $t$ tabel yaitu 1,999 dan signifikansi sebesar 0,000 lebih kecil dari 0,05 maka dapat disimpulkan 
bahwa variabel kemampuan berpengaruh signifkan terhadap kinerja karyawan.

3) Secara parsial dapat disimpulkan bahwa kepribadian berpengaruh positif tapi tidak signifikan terhadap kinerja karyawan. Hal ini dibuktikan dengan uji secara parsial diperoleh koefisien regresi untuk variabel kepribadian bernilai positif $(0,280)$ yang berarti bahwa setiap peningkatan kepribadian akan mempengaruhi peningkatan kinerja karyawan. Sedangkan untuk uji $\mathrm{t}$ diperoleh nilai $\mathrm{t}$ hitung sebesar 1,859 lebih kecil dari nilai t tabel yaitu 1,999 dan signifikansi sebesar 0,068 lebih besar dari 0,05 maka dapat disimpulkan bahwa variabel kepribadian tidak berpengaruh signifkan terhadap kinerja karyawan.

4) Secara parsial dapat disimpulkan bahwa persepsi berpengaruh positif tapi tidak signifikan terhadap kinerja karyawan. Hal ini dibuktikan dengan uji secara parsial diperoleh koefisien regresi untuk variabel kepribadian bernilai positif $(0,054)$ yang berarti bahwa setiap peningkatan kepribadian akan mempengaruhi peningkatan kinerja karyawan. Sedangkan untuk uji t diperoleh nilai t hitung sebesar 0,471 lebih kecil dari nilai t tabel yaitu 1,999 dan signifikansi sebesar 0,639 lebih besar dari 0,05 maka dapat disimpulkan bahwa variabel kepribadian tidak berpengaruh signifkan terhadap kinerja karyawan.

5) Secara parsial dapat disimpulkan bahwa sikap berpengaruh positif dan signifikan terhadap kinerja karyawan. Hal ini dibuktikan dengan uji secara parsial diperoleh koefisien regresi untuk variabel kemampuan bernilai positif $(0,611)$ yang berarti bahwa setiap peningkatan sikap akan mempengaruhi peningkatan kinerja karyawan. Sedangkan untuk uji t diperoleh nilai t hitung sebesar 3,760 lebih besar dari nilai t tabel yaitu 1,999 dan signifikansi sebesar 0,000 lebih kecil dari 0,05 maka dapat disimpulkan bahwa variabel sikap berpengaruh signifkan terhadap kinerja karyawan.

\section{DAFTAR PUSTAKA}

Alex Sobur. 2003. Psikologi Umum. Bandung: Pustaka Setia.

Arikunto, Suharsimi. 2006. Prosedur Penelitian suatu Pendekatan Praktik. Jakarta: Rineka Cipta.

Azwar, Saifudin. 2012. Penyusunan skala psikologi. Yogyakarta: Pustaka Pelajar Offset.

Walgito. 2010. Pengantar Psikologi Umum. Yogyakarta: C.V Andi Offset.

Buyung. A. Syafei, 2007, Evaluasi Kinerja. Palembang: Program Pascasarjana Universitas Bina Darma,

Dharma, Agus. 2003. Manajemen Prestasi Kerja: Pedoman Praktis Bagi Para Penyelia untuk Meningkatkan Prestasi Kerja, Edisi Kelima. Jakarta: Radjawali Pers.

Gerungan, W.A. 2009. Psikologi Sosial. Bandung: PT Refika Asitama.

Hasan, M. Iqbal. 2002. Pokok-Pokok Materi Metodologi Penelitian dan Aplikasinya. Bogor : Ghalia Indonesia.

Hasibuan, S.P. Malayu, 2009. Manajemen Sumber Daya Manusia, cetakan ketujuh Penerbit PT. Bumi Aksara, Jakarta.

Ivancevich, J.Matteson dan Michael. T. 2006. Perilaku dan Manajemen Organisasi. Jakarta: Erlangga.

Kriyantono, Rachmat, 2006, Teknik Praktis Riset Komunikasi, Jakarta: Kencana. Prenada Group. 
Mangkunegara, A.A Anwar Prabu. 2010. Evaluasi Kinerja SDM. Bandung: PT Revika Aditama.

Miftah Thoha. 2003, Kepemimpinan Dalam Manajemen. Jakarta : PT. Raja Grafindo Persada.

Perry Roy Hilton and Charlotte Brownlow. 2004. SPSS Explained. East Sussex : Routledge.

Riduwan dan Akdom, 2007, Rumus dan Data Dalam Analisis Statistik, cetakan kedua, Penerbit: Alfabeta, Bandung.

Rivai, Veithzal. 2006. Manajemen Sumber Daya Manusia untuk Perusahaan. Jakarta: Raja Grafindo.

Robbins Stephen P, Timothy A. Judge. 2007. Perilaku Organisasi. Terj: Benyamin Molan. New Jersey Prentice Hall, Inc.

2008. Perilaku Organisasi. Jakarta: Salemba Empat.

Sedarmayanti. 2009. Good Governance (Kepemerintahan Yang Baik) Dalam Rangka Otonomi Daerah : Upaya Membangun Organisasi Efektif dan Efisien Melalui Rekstrukturisasi dan Pemberdayaan, Cetakan kedua, Mandar Maju, Bandung.

Simanjuntak, Payaman. 2011. Manajemen dan Evaluasi Kinerja - Edisi Ketiga. Jakarta : Lembaga Penerbit Fakultas Ekonomi Universitas Indonesia.

Sinamo, Jansen H. 2002. Etos Kerja 21 Etos Kerja Profesional di Era Digital Global, Ed 1. Jakarta: Institut Darma Mahardika.

Slameto. 2010. Belajar dan Faktor-Faktor yang Mempengaruhinya. Jakarta: Rineka Cipta.

Soelaiman, 2007, Manajemen Kinerja ; Langkah Efektif untuk Membangun, Mengendalikan dan Evaluasi Kerja, Cetakan Kedua, Jakarta: PT. Intermedia Personalia Utama.
Sopiah. 2008. Perilaku Organisasional. Yogyakarta: Andi.

Sriwati Bukit. 2010. Pendidikan Karakter. http://sumut.kemenag.go.id/file/file//ydo m1335154408.pdf.

Tampubolon, Manahan P. 2008. Perilaku Keorganisasian, Edisi Kedua. Cetakan Pertama, Jakarta: Ghalia Indonesia.

Yuwono, dkk. 2005. Psikologi Industri dan Organisasi. Surabaya :Universitas Airlangga.

Zaim Elmubarok. 2009. Membumikan Pendidikan Nilai. Bandung: Alfabeta. 